\title{
Effect of Concentration of Entomopathogenic Nematodes (Steinernema spp.) to Bemisia tabaci Genn. (Hemiptera; Aleyrodidae) On Red Chili Plants
}

\author{
Toto Sunarto $^{1 *}$, Fahira Endaningsih Pubarianto ${ }^{2}$ \\ ${ }^{1}$ Departement of Plant Pests and Diseases, Agriculture Faculty, Universitas Padjadjaran, Jatinangor, West Java 45363 \\ ${ }^{2}$ Student of Agrotechnology Study Program, Faculty of Agriculture, Universitas Padjadjaran \\ *Corresponding Author : toto.sunarto@unpad.ac.id
}

Received October 04, 2021; revised November 12, 2021; accepted December 02, 2021

\begin{abstract}
Bemisia tabaci is an important pest on red chili plants. The entomopathogenic nematodes Steinernema spp. has the potential to control insect pest populations. The purpose of this study was to obtain the concentration of Steinernema spp. the most effective in controlling B. tabaci on red chili plants. The experiment was conducted at the Greenhouse, Faculty of Agriculture, Universitas Padjadjaran, Jatinangor, from January to September 2020. The study used experimental methods invitro and in-vivo. The in-vitro experiment used a completely randomized design to observe the mortality of $B$. tabaci. The invivo experiment used a Randomized Block Design to observe the population of B. tabaci. The experiment consisted of seven treatments and four replications. The treatments consisted of: control (without Steinernema spp.), 50, 100, 150, 200, 250, and $300 \mathrm{IJ} / \mathrm{ml}$ (IJ = third infective juvenile). Each treatment was infested with 20 second nymphs $B$. tabaci and using red chili plants 30 days after planting. The results showed that the entomopathogenic nematode Steinernema spp. at a concentration of $300 \mathrm{IJ} / \mathrm{ml}$, the most effective in causing mortality of $B$. Tabaci and at concentration of $100 \mathrm{IJ} / \mathrm{ml}$ can suppress $B$. tabaci population on chilli plant at lower level in 12 days after application.
\end{abstract}

Keywords: Bemisia tabaci, entomopathogenic nematodes, red chili plants

\author{
ABSTRAK \\ Pengaruh Konsentrasi Nematoda Entomopatogen Steinernema spp. terhadap Bemisia tabaci Genn. \\ (Hemiptera: Aleyrodidae) pada Tanaman Cabai Merah
}

Bemisia tabaci merupakan hama penting pada tanaman cabai merah. Nematoda entomopatogen Steinernema spp. memiliki potensi dalam mengendalikan populasi serangga hama. Tujuan penelitian ini untuk mendapatkan konsentrasi Steinernema spp. yang paling efektif dalam mengendalikan B. tabaci pada tanaman cabai merah. Percobaan dilakukan di Rumah Kaca, Fakultas Pertanian Universitas Padjadjaran, Jatinangor pada bulan Januari sampai September 2020. Penelitian menggunakan metode eksperimen secara in-vitro dan in-vivo. Percobaan in-vitro menggunakan Rancangan Acak Lengkap untuk mengamati mortalitas B. tabaci. Percobaan in-vivo menggunakan Rancangan Acak Kelompok untuk mengamati populasi $B$. tabaci. Percobaan terdiri dari tujuh perlakuan dan empat ulangan. Perlakuan terdiri dari: kontrol (tanpa Steinernema spp.), $50,100,150,200,250$, dan $300 \mathrm{JI} / \mathrm{ml}$ ( $\mathrm{JI}=$ juvenile infektif ketiga). Tiap perlakuan diinfestasi dengan 20 nimfa kedua $B$. tabaci dan menggunakan tanaman cabai merah umur 30 hari setelah tanam. Hasil penelitian menunjukkan bahwa nematoda entomopatogen Steinernema spp. pada konsentrasi $300 \mathrm{JI} / \mathrm{ml}$ paling tinggi menyebabkan mortalitas B. tabaci dan pada konsentrasi $100 \mathrm{JI} / \mathrm{ml}$ dapat menekan hingga tingkat rendah populasi B. tabaci pada 12 hari setelah aplikasi pada tanaman cabai.

Kata Kunci: Bemissia tabaci, nematoda entomopatogen, tanaman cabai merah

\section{PENDAHULUAN}

Nematoda entomopatogen (NEP) merupakan salah satu agens biokontrol yang banyak dikembangkan untuk pengendalian serangga hama pada tanaman pangan, perkebunan, dan hortikultura (Grewal et al., 2005). Nematoda famili Steinernematidae dan Heterorhabditidae banyak dimanfaatkan sebagai agens biokontrol (Glazer \& Lewis, 2000). NEP genera Heterorhabditis dan Steinernema adalah agens pengendali biologis penting yang digunakan untuk mengendalikan serangga hama (Shapiro-Ilan et al., 2020)
Kelebihan dari famili Steinernematidae dan Heterorhabditidae yaitu tidak berbahaya bagi mamalia, mempunyai virulensi yang tinggi, mudah diperbanyak secara in-vivo maupun in-vitro, serta kompatibel dengan pestisida lain (Kaya \& Gaugler, 1993).

Pemanfaatan NEP sebagai agen biokontrol tidak menimbulkan efek negatif terhadap hama bukan sasaran, termasuk serangga berguna, vertebrata, dan manusia (Boemare et al., 1996). Pemanfaatan NEP Steinernema spp. sebagai agens biokontrol, salah satunya sebagai agens biokontrol hama kutu kebul (Bemisia tabaci). 
Bemisia tabaci adalah salah satu serangga hama paling penting secara ekonomi pada bermacam tanaman sayuran ( $\mathrm{Li}$ et al., 2021). B. tabaci merupakan hama penting pada tanaman cabai merah. Kerusakan yang diakibatkan oleh $B$. tabaci meliputi kerusakan secara langsung akibat dari cairan sel daun dihisap oleh hama, daun menjadi klorosis dan gugur, tanaman menjadi kerdil sehingga mengurangi pertumbuhan dan hasil, dan kerusakan secara tidak langsung, embun madu yang dikeluarkan oleh hama dapat menimbulkan serangan embun jelaga yang dapat mengurangi laju proses fotosintesis (Setiawati et al., 2008).

Hasil pengujian NEP pada kutu kebul Trialeurodes vaporariorum dapat membunuh nimfa instar dua dan imago serangga hama. Nilai LC $_{50}$ Steinernema spp. adalah $84 \mathrm{IJ} / \mathrm{ml}$ untuk nimfa instar dua dan 143,1 IJ/ml untuk fase imago. Mortalitas $T$. vaporariorum meningkat seiring dengan peningkatan konsentrasi NEP dari 25, 50, 100, 150, 200, dan 250 $I J / m l$ (Rezaei et al., 2015). Hasil penelitian An et al. (2016) menunjukkan bahwa pada pengamatan hari ketujuh, B. tabaci betina meletakkan telur lebih banyak pada tanaman dengan perlakuan kontrol, dan meletakkan telur lebih sedikit pada tanaman yang telah diinfestasi dengan NEP. Aplikasi Steinernema spp. pada konsentrasi $160 \mathrm{IJ} / \mathrm{ml}$ pada tanaman dapat mengurangi populasi $B$. tabaci nimfa instar dua secara nyata (Cuthbertson et al., 2003).

Pengendalian $B$. tabaci di Indonesia umumnya menggunakan insektisida, dan keberadaan $B$. tabaci yang terdapat di bawah daun, sehingga sulit untuk dijangkau dengan insektisida (Ardeh, 2004). Menurut (de Barro, 2005 dan Sugiyama, 2005) bahwa penggunaan insektisida kurang efektif karena tubuh serangga dilapisi lilin sehingga sulit ditembus oleh bahan aktif insektisida. Penggunaan pestisida memiliki dampak negatif yaitu resistensi hama, resurgensi, keracunan, dan pencemaran lingkungan (Prabowo \& Indrayani, 2009). Oleh karena itu perlu dilakukan penelitian mengenai efektivitas konsentrasi nematoda entomopatogen terhadap B. tabaci pada tanaman cabai merah. Tujuan penelitian untuk mendapatkan konsentrasi nematoda entomopatogen Steinernema spp. yang efektif terhadap mortalitas nimfa B. tabaci pada tanaman cabai merah.

\section{BAHAN DAN METODE}

Percobaan dilakukan di Rumah Kaca, Fakultas Pertanian Universitas Padjadjaran, Jatinangor. Percobaan dilaksanakan pada bulan JanuariSeptember 2020. Alat-alat yang digunakan adalah beaker glass, pipet tetes, mikroskop, kuas, hand sprayer, polybag ukuran $30 \mathrm{~cm} \times 40 \mathrm{~cm}$, plastik mika bening ukuran $70 \mathrm{~cm} \times 40 \mathrm{~cm}$, kain kasa, cup plastik, toples plastik, sekop, kertas label, alat tulis, kamera.

Bahan-bahan yang digunakan adalah benih cabai merah, nimfa B. tabaci, Steinernema spp. juvenil infektif koleksi Divisi Laboratorium Nematologi Tumbuhan, Departemen Hama dan
Penyakit Tumbuhan, Fakultas Pertanian Universitas Padjadjaran, pupuk kompos (kotoran kambing dan sisa-sisa pakan kambing), pupuk cair (NPK lengkap), tanah, dan akuades.

Penelitian terdiri dari dua percobaan, yaitu:

1. Uji nematoda entomopatogen Steinernema spp. terhadap mortalitas B. tabaci Penelitian menggunakan metode percobaan dengan Rancangan Acak Lengkap (RAL), terdiri dari 7 perlakuan dan 4 ulangan. Data hasil pengamatan dianalisis dengan analisis probit untuk mengetahui nilai $\mathrm{LC}_{50}$ nya.

2. Keefektifan nematoda entomopatogen Steinernema spp. terhadap B. tabaci Penelitian menggunakan metode percobaan dengan Rancangan Acak Kelompok (RAK), terdiri dari 7 perlakuan dan 4 ulangan.

Perlakuan pada kedua percobaan terdiri dari: kontrol (tanpa Steinernema spp.), konsentrasi Steinernema spp. 50, 100, 150, 200, 250, dan 300 $\mathrm{JI} / \mathrm{ml}$. Data hasil pengamatan dianalisis dengan ANOVA, sedangkan untuk mengetahui perbedaan antara rata-rata perlakuan diuji dengan Uji Jarak Berganda Duncan pada taraf nyata 5\%. Analisis data menggunakan software SPSS versi 25.0.

\section{Penanaman Cabai Merah}

Media tanam yang digunakan adalah tanah, pupuk kompos atau pupuk kandang jenis kotoran kambing, dan arang sekam dengan perbandingan 3:2:1 lalu diaduk hingga tercampur rata (BPTP Sumbar, 2017). Benih cabai merah direndam dengan air hangat $\left(50^{\circ} \mathrm{C}\right)$ selama 6 jam, kemudian benih ditanam di seed tray.

Benih cabai yang telah berumur 14 hari (memiliki 4 daun), dipindah tanam pada polybag ukuran $40 \mathrm{~cm}$ x $30 \mathrm{~cm}$. Media tanam yang digunakan adalah tanah dan pupuk kompos dengan perbandingan 1:1 lalu diaduk hingga tercampur rata (BPTP Sumbar, 2017). Jarak antar polybag adalah $20 \mathrm{~cm}$ x $30 \mathrm{~cm}$. Pemupukan diaplikasikan saat tanaman berumur satu bulan dengan aplikasi pupuk NPK dengan cara $30 \mathrm{~g}$ pupuk NPK dilarutkan dalam $1 \mathrm{~L}$ air (konsentrasi 30 $\%)$. Larutan pupuk disiramkan pada tanaman sebanyak $200 \mathrm{ml}$ per polybag, satu kali dalam 10 hari.

\section{Perbanyakan Nematoda Steinernema spp.}

Inokulum nematoda entomopatogen

Steinernema spp. berasal dari Divisi Laboratorium Nematologi, Departemen Hama dan Penyakit Tumbuhan, Fakultas Pertanian, Univesitas Padjadjaran.

Perbanyakan Steinernema spp. dilakukan dengan metode White trap yaitu: ulat hongkong (Tenebrio molitor) dimasukkan ke dalam cawan petri kemudian diinokulasi dengan Steinernema spp., kemudian diinkubasi selama 3 hari. T. molitor yang telah mati diambil kemudian diletakkan di atas 
petridish kecil yang telah dialasi dengan kertas saring dan cawan petri tersebut disimpan pada cawan petri yang lebih besar, lalu ditambahkan air setengah dari tinggi cawan petri. Setelah 5 hari, Steinernema spp. akan masuk ke dalam air dan siap dipanen.

\section{Perbanyakan Nimfa Bemisia tabaci}

Perbanyakan B. tabaci dilakukan di rumah kaca, Fakultas Pertanian Universitas Padjadjaran. Tanaman cabai merah dimasukkan ke dalam tempat berbentuk kotak dan ditutupi kain kasa. Satu atau beberapa daun tanaman tomat yang di bawahnya terdapat telur dan nimfa $B$. tabaci diambil dari lapangan lalu diletakkan pada tanaman cabai untuk diperbanyak. Pada 3-5 hari setelah infestasi, B. tabaci telah berkembang biak. Tanaman dipelihara selama 12 hari, sehingga $B$. tabaci mulai memasuki nimfa instar dua.

\section{Pelaksanaan Percobaan}

Uji nematoda entomopatogen Steinernema spp. terhadap mortalitas $B$. tabaci

Uji mortalitas dilakukan secara in-vitro. Tiap perlakuan menggunakan cawan petri yang diisi dengan daun cabai, kemudian diinfestasi dengan 20 nimfa instar kedua $B$. tabaci menggunakan kuas halus. Selanjutnya disemprot dengan satu $\mathrm{ml}$ nematoda entomopatogen Steinernema spp. sesuai perlakuan dengan menggunakan hand sprayer.
Pengamatan jumlah nimfa instar kedua $B$. tabaci yang mati dilakukan pada 24, 48, 72, 96, dan 120 jam setelah aplikasi Steinernema spp.

\section{Keefektifan nematoda entomopatogen Steinernema spp. terhadap B. tabaci}

Tanaman cabai merah yang telah berumur 4 MST (minggu setelah tanam) diinfestasi dengan masing-masing 20 nimfa $B$. tabaci per polybag menggunakan kuas halus dan disungkup dengan mika serta diletakkan di rumah kaca. Aplikasi Steinernema spp. sesuai dengan perlakuan dan disemprotkan pada tanaman cabai.

Pengamatan kepadatan populasi B. tabaci dilakukan pada setiap 3 hari sampai 30 hari setelah aplikasi.

\section{HASIL DAN PEMBAHASAN}

\section{Mortalitas Nimfa Bemisia tabaci}

Nematoda entomopatogen Steinernema spp. berpengaruh terhadap peningkatan mortalitas nimfa $B$. tabaci. Hasil pengamatan menunjukkan adanya hubungan antara mortalitas nimfa B. tabaci dengan Steinernema spp. yang setiap harinya mengalami peningkatan (Gambar 1). Tinggi rendahnya angka mortalitas dipengaruhi oleh pengaplikasian konsentrasi Steinernema spp. Semakin tinggi konsentrasi Steinernema spp., mengakibatkan mortalitas nimfa B. tabaci semakin tinggi.

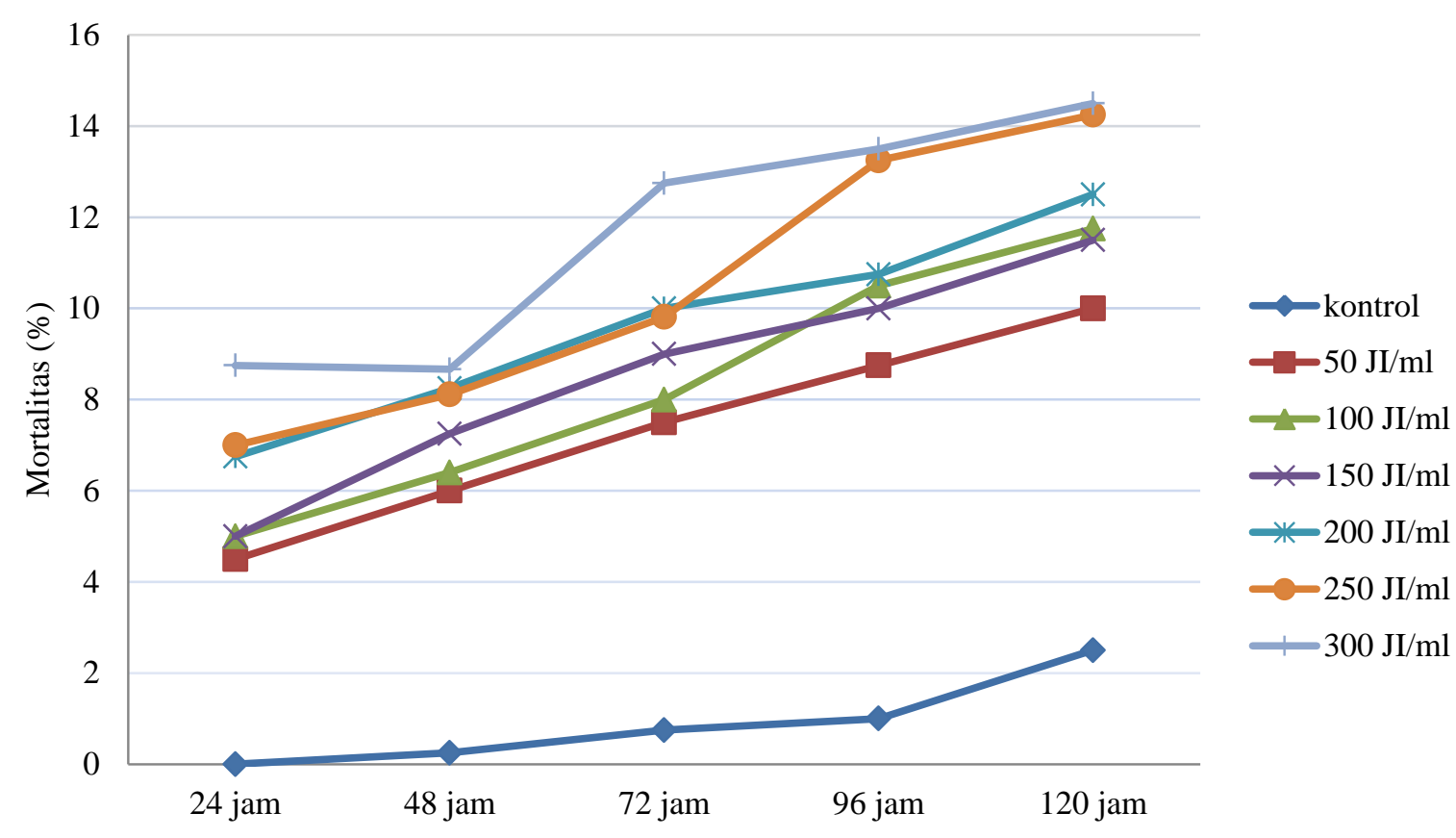

Jam setelah perlakuan

Gambar 1. Mortalitas nimfa B. tabaci pada berbagai konsentrasi nematoda Steinernema spp. 
Rata-rata mortalitas nimfa $B$. tabaci terendah terdapat pada kontrol (tanpa Steinernema spp.), yaitu pada pengamatan $24,48,72,96$, dan 120 JSA (jam setelah aplikasi) Steinernema spp. masing-masing adalah $0,0,25,0,75,1$, dan 2,5\%. Rata-rata mortalitas B. tabaci tertinggi terdapat pada aplikasi Steinernema spp. $300 \mathrm{JI} / \mathrm{ml}$ yaitu pada pengamatan 24, 48, 72, 96, dan 120 JSA, masing-masing adalah 8,75, 8,67, 12,75, 13,5, dan $14,5 \%$.

Berdasarkan hasil analisis probit menunjukkan bahwa nilai $\mathrm{LC}_{50}$ menurun mulai dari 24 jam hingga
120 jam setelah aplikasi. Semakin kecil nilai LC menunjukkan semakin berpengaruhnya konsentrasi Steinernema spp. yang diaplikasikan (Tabel 1). Nilai $\mathrm{LC}_{50}$ mengalami penurunan seiring dengan meningkatnya mortalitas nimfa. Nilai $\mathrm{LC}_{50}$ mengalami penurunan dari pengamatan 24 jam hingga 48 jam yaitu sebesar $62 \%$. Penurunan nilai $\mathrm{LC}_{50}$ pada 48 jam hingga 72 jam yaitu $4 \%$. Penurunan nilai $\mathrm{LC}_{50}$ pada 72 jam hingga 96 jam yaitu $0,8 \%$. Penurunan nilai $\mathrm{LC}_{50}$ dari 96 jam hingga 120 jam yaitu 0,3\%.).

Tabel 1. Parameter regresi probit mortalitas Bemisia tabaci.

\begin{tabular}{ccccc}
\hline Waktu & $\mathrm{a} \pm \mathrm{SE}$ & $\mathrm{b} \pm \mathrm{SE}$ & $\mathrm{LC}_{50}$ & $(\%)$ \\
\hline 24 Jam & $3,372 \pm 0,513$ & $0,526 \pm 0,234$ & 0,118 & $11,80 \%$ \\
48 Jam & $3,676 \pm 0,506$ & $0,479 \pm 0,230$ & 0,056 & $5,60 \%$ \\
72 Jam & $3,361 \pm 0,143$ & $0,742 \pm 0,070$ & 0,016 & $1,60 \%$ \\
96 Jam & $3,486 \pm 0,254$ & $0,784 \pm 0,125$ & 0,008 & $0,80 \%$ \\
120 Jam & $3,715 \pm 0,161$ & $0,730+0,079$ & 0,005 & $0,50 \%$ \\
\hline
\end{tabular}

\begin{tabular}{ll}
\hline Keterangan: \\
$\mathrm{a}$ & : Intersep garis regresi \\
$\mathrm{b}$ & : Kemiringan garis regresi (slope) \\
$\mathrm{SE}$ & : Standard Error \\
$\mathrm{LC}$ & : Lethal concentration
\end{tabular}

Timbulnya efek mortalitas pada nimfa $B$. tabaci karena adanya bakteri simbion yang berkembang biak di dalam perut serangga dan dapat membunuh serangga sebagai akibat keracunan darah (septicemia) dengan menyesuaikan kondisi sesuai pertumbuhan dan reproduksi nematoda di dalam tubuh serangga (Chaerani et al., 2007). Nimfa $B$. tabaci yang terinfeksi oleh nematoda entomopatogen Steinernema spp. ditandai dengan warna putih merata. Hal itu karena aktifitas Steinernema spp. dalam tubuh serangga yang merusak seluruh organ, sehingga warna transparan berubah menjadi putih keruh.

\section{Populasi Bemisia tabaci pada Tanaman Cabai Merah}

Aplikasi Steinernema spp. berpengaruh dalam menurunkan kepadatan populasi Bemisia tabaci dibandingkan dengan kontrol (tanpa Steinernema spp.) pada 3 sampai 30 HSA (hari setelah aplikasi) (Tabel 2). Pada 3 HSA dan 6 HSA kepadatan populasi B. tabaci terendah terdapat pada aplikasi Steinernema spp. $250 \mathrm{JI} / \mathrm{ml}$ dan $300 \mathrm{JI} / \mathrm{ml}$ yang berbeda nyata dengan kepadatan populasi $B$. tabaci pada aplikasi Steinernema spp. 50, 100, 150, $200 \mathrm{JI} / \mathrm{ml}$ dan kontrol. Pada 9 HSA kepadatan B. tabaci terendah terdapat pada aplikasi Steinernema spp. 250, 300, 200, 150 $\mathrm{JI} / \mathrm{ml}$ yang berbeda nyata dengan kepadatan $B$. tabaci pada aplikasi Steinernema spp. 50, $100 \mathrm{JI} / \mathrm{ml}$, dan kontrol. Hal ini karena pada pengamatan 3-9 HSA terjadi penurunan populasi B. tabaci. Hal ini didukung oleh hasil penelitian Bastidas et al. (2014) yang menyatakan bahwa NEP cocok digunakan untuk aplikasi pada daun terhadap T. vaporariorum. Selain itu, Laznic et al. (2011) melaporkan bahwa Steinernema feltiae efektif terhadap nimfa instar kedua $T$. vaporariorum, hal ini karena imobilitas nimfa instar kedua melekat pada daun, akibatnya meningkatkan NEP kontak dan penetrasi.

Pada 12 HSA hingga 30 HSA kepadatan $B$. tabaci tidak berbeda nyata pada aplikasi Steinernema spp. $50 \mathrm{JI} / \mathrm{ml}, 100 \mathrm{JI} / \mathrm{ml}, 150 \mathrm{JI} / \mathrm{ml}, 200 \mathrm{JI} / \mathrm{ml}, 250$ $\mathrm{JI} / \mathrm{ml}$, dan $300 \mathrm{JI} / \mathrm{ml}$ tetapi berbeda nyata dengan kontrol, dikarenakan pada 12 HSA populasi B. tabaci yang diberi perlakuan sudah mulai mati. Pada pengamatan 15 HSA hingga $30 \mathrm{HSA}$, populasi $B$. tabaci pada aplikasi Steinernema spp. $50 \mathrm{JI} / \mathrm{ml}, 100$ $\mathrm{JI} / \mathrm{ml}, 150 \mathrm{JI} / \mathrm{ml}, 200 \mathrm{JI} / \mathrm{ml}, 250 \mathrm{JI} / \mathrm{ml}$, dan $300 \mathrm{JI} / \mathrm{ml}$ yaitu 0 (nol) yang berarti bahwa semua serangga mengalami mortalitas akibat infeksi NEP Steinernema spp. sedangkan pada kontrol (tanpa Steinernema spp.) setiap harinya bertambah karena tidak terinfeksi.

Tingginya mortalitas pada serangga yang diakibatkan oleh nematoda entomopatogen karena reproduksi nematoda yang cepat serta adanya bakteri simbion di dalam nematoda. Bakteri simbion mampu membunuh serangga dalam waktu relatif singkat, yaitu 24-48 jam, mengkoloni dan menyediakan makanan bagi nematoda, sedangkan nematoda berperan sebagai vektornya. Nematoda ini bersifat aktif dan mampu mencapai serangga yang terletak dalam habitat yang tersembunyi di dalam tanah (Chaerani, 1996). NEP Steinernema spp. juga memiliki keuntungan bagi bakteri simbion yaitu mampu melindungi bakteri dari lingkungan eksternal yang merugikan, mempercepat terjadinya penetrasi ke dalam hemocoel serangga dan memungkinkan adanya 
toksin yang dikeluarkan oleh serangga (protein antibakteri) (Hazir et al., 2003).

Populasi B. tabaci pada kontrol (tanpa Steinernema spp.) meningkat setiap harinya karena ketersediaan makanan yang cukup dan tidak ada organisme lain yang mengganggu perkembangbiakan B. tabaci. Berbeda dengan populasi B. tabaci pada aplikasi Steinernema spp. $50 \mathrm{JI} / \mathrm{ml}, 100 \mathrm{JI} / \mathrm{ml}, 150$
$\mathrm{JI} / \mathrm{ml}, 200 \mathrm{JI} / \mathrm{ml}, 250 \mathrm{JI} / \mathrm{ml}$, dan $300 \mathrm{JI} / \mathrm{ml}$ yang semakin menurun, hal itu karena infeksi Steinernema spp. pada $B$. tabaci pada saat pengaplikasian. Perlakuan Steinernema spp. $100 \mathrm{JI} / \mathrm{ml}$ efektif menekan populasi B. tabaci pada 12 hari setelah aplikasi dan populasi terkendali sepenuhnya pada 15 hari setelah aplikasi.

Tabel 2. Kepadatan populasi Bemisia tabaci pada tanaman cabai merah

\begin{tabular}{|c|c|c|c|c|c|c|c|c|c|c|}
\hline \multirow[t]{2}{*}{ Perlakuan } & \multicolumn{10}{|c|}{$\begin{array}{l}\text { Rata-rata kepadatan populasi Bemisia tabaci } \\
\text { (ekor per tanaman) pada n (HSA) }\end{array}$} \\
\hline & 3 & & 6 & & 9 & & 12 & & 15 & \\
\hline Kontrol & 38,75 & $\mathrm{~d}$ & 9,04 & $\mathrm{~d}$ & 10,69 & $\mathrm{c}$ & 12,07 & $\mathrm{~b}$ & 14,36 & $\mathrm{~b}$ \\
\hline Steinernema spp. $50 \mathrm{Jl} / \mathrm{ml}$ & 27,50 & $\mathrm{c}$ & 4,43 & $\mathrm{c}$ & 3,16 & $\mathrm{~b}$ & 0,60 & $\mathrm{a}$ & 0,00 & $\mathrm{a}$ \\
\hline Steinernema spp.100 Jl/ml & 26,00 & $\mathrm{bc}$ & 4,32 & $\mathrm{c}$ & 3,09 & $\mathrm{~b}$ & 0,25 & $\mathrm{a}$ & 0,00 & $\mathrm{a}$ \\
\hline Steinernema spp.150 Jl/ml & 24,00 & $\mathrm{bc}$ & 3,30 & $\mathrm{~b}$ & 1,10 & $\mathrm{a}$ & 0,00 & $\mathrm{a}$ & 0,00 & $\mathrm{a}$ \\
\hline Steinernema spp.200 Jl/ml & 22,00 & $\mathrm{~b}$ & 3,11 & $\mathrm{~b}$ & 0,75 & $\mathrm{a}$ & 0,00 & $\mathrm{a}$ & 0,00 & $\mathrm{a}$ \\
\hline Steinernema spp. $250 \mathrm{Jl} / \mathrm{ml}$ & 14,00 & $\mathrm{a}$ & 2,06 & $\mathrm{a}$ & 0,00 & $\mathrm{a}$ & 0,00 & $\mathrm{a}$ & 0,00 & $\mathrm{a}$ \\
\hline Steinernema spp.300 Jl/ml & 11,75 & $\mathrm{a}$ & 1,46 & $\mathrm{a}$ & 0,00 & $\mathrm{a}$ & 0,00 & $\mathrm{a}$ & 0,00 & $\mathrm{a}$ \\
\hline
\end{tabular}

Perlakuan

Rata-rata kepadatan populasi Bemisia tabaci (ekor per tanaman) pada $n$ (HSA)

\begin{tabular}{|c|c|c|c|c|c|c|c|c|c|c|}
\hline \multirow[b]{3}{*}{ Kontrol } & \multirow{2}{*}{\multicolumn{2}{|c|}{18}} & \multirow{2}{*}{\multicolumn{2}{|c|}{21}} & & & & & & \\
\hline & & & & & \multicolumn{2}{|l|}{24} & \multicolumn{2}{|l|}{27} & \multicolumn{2}{|l|}{30} \\
\hline & 15.20 & $\mathrm{~b}$ & $16 ., 95$ & $\mathrm{~b}$ & 17,55 & $\mathrm{~b}$ & 18,52 & $\mathrm{~b}$ & 19,89 & $\mathrm{~b}$ \\
\hline Steinernema spp,50 Jl/ml & 0,00 & $\mathrm{a}$ & 0,00 & a & 0,00 & a & 0,00 & a & 0,00 & a \\
\hline Steinernema spp,100 Jl/ml & 0,00 & $\mathrm{a}$ & 0,00 & $\mathrm{a}$ & 0,00 & $\mathrm{a}$ & 0,00 & $\mathrm{a}$ & 0,00 & $\mathrm{a}$ \\
\hline Steinernema spp,150 Jl/ml & 0,00 & $\mathrm{a}$ & 0,00 & $\mathrm{a}$ & 0,00 & $\mathrm{a}$ & 0,00 & $\mathrm{a}$ & 0,00 & $\mathrm{a}$ \\
\hline Steinernema spp,200 Jl/ml & 0,00 & $\mathrm{a}$ & 0,00 & $\mathrm{a}$ & 0,00 & $\mathrm{a}$ & 0,00 & $\mathrm{a}$ & 0,00 & a \\
\hline Steinernema spp,250 J1/ml & 0,00 & $\mathrm{a}$ & 0,00 & $\mathrm{a}$ & 0,00 & a & 0,00 & $\mathrm{a}$ & 0,00 & a \\
\hline Steinernema spp,300 Jl/ml & 0,00 & $\mathrm{a}$ & 0,00 & $\mathrm{a}$ & 0,00 & $\mathrm{a}$ & 0,00 & $\mathrm{a}$ & 0,00 & $\mathrm{a}$ \\
\hline
\end{tabular}

Keterangan: $\quad$ HSA (Hari Setelah Aplikasi)

Angka yang diikuti huruf yang sama pada setiap kolom tidak berbeda nyata menurut uji Duncan pada taraf nyata $5 \%$.

\section{KESIMPULAN DAN SARAN}

Berdasarkan hasil dan pembahasan, dapat disimpulan sebagai berikut:

1. Nematoda entomopatogen Steinernema spp. pada konsentrasi $300 \mathrm{JI} / \mathrm{ml}$ paling tinggi dalam menyebabkan mortalitas $B$. tabaci pada tanaman cabai merah (14,5\% pada 120 jam setelah aplikasi).

2. Nematoda entomopatogen Steinernema spp. berpengaruh dalam menekan kepadatan populasi B. tabaci pada tanaman cabai merah. Nematoda entomopatogen Steinernema spp. pada konsentrasi $100 \mathrm{JI} / \mathrm{ml}$ dapat mengendalikan populasi $B$. tabaci pada tanaman cabai merah pada 12 hari setelah aplikasi.

\section{DAFTAR PUSTAKA}

BPTP (Balai Pengkajian Teknologi Pertanian) Sumbar. 2017. Budidaya Cabai dalam Pot/Polybag.http://sumbar.litbang.pertanian.go. id/index.php/info-tek/1022-budidaya-cabaidalam-pot-polybag. (diakses 18 Desember 2019).

An R, Orellana D, Phelan LP, Canas L, \& Grewal P. 2016. Entomopathogenic nematodes induce systemic resistance in tomato against Spodoptera exigua, Bemisia tabaci and Pseudomonas syringae. Biological Control 93: 24-29.

Ardeh MJ. 2004. Whitefly control potential of Eretmocerus parasitoids with different reproductive modes. [Thesis]. Wagenigen Universiteit. Germany. 
Bastidas B, Edgar P, \& San-Blas E. 2014. Size does matter: The live cycle of Steinernema spp. In micro-insect hosts. Journal of Invertebrate Pathology 121: 46-55.

Boemare N, Laumond C, \& Mauleon H. 1996. The entomopathogenic nematode-bacterium complex: biology, life cycle and vertebrate safety. Biocontrol Sci. and Tech. 6(3): 333345.

Chaerani M. 1996. Nematoda Patogen Serangga. Bogor : Balai Penelitian Bioteknologi Tanaman Pangan Bogor.

Chaerani, Suryadi Y, Priyatno TP, Koswanudin D, Rahmat U, Sujatmo, Yusuf \& Griffin CT. 2007. Isolasi nematoda patogen serangga Steinernema dan Heterorhabditis. Jurnal HPT Tropika. 7( 1): $1-9$.

Cuthbertson AG, Head J, Walters KF, \& Gregory SA. 2003. The efficacy of the entomopathogenic nematode, Steinernema feltiae, against the immature stages of Bemisia tabaci. J Invertebr Pathol. 2003 Jul; 83(3): 267-9.

De Barro PJ. 2005. Bemisia tabaci Biotype B, a Review of its Biology, Distribution and Contro. CSIRO Division Entomology Technical Paper. 36: 1-58.

Glazer I \& Lewis EE. 2000. Bioassays for entomopathogenic nematodes. Pp. 220-245 in Navon, A. and K.R.S. Ascher (Ed.). Bioassays of entomopathogenic microbes and nematodes. CAB International Pub. UK.

Grewal PS. 2005. Formulation and application technology. Pp. 311-332 in Gaugler R. (Ed). Entomopathogenic Nematology CABI Publishing, vol. 15. CAB International, Wallingford.

Kaya MG. \& Gaugler. 1993. Efficiacy Against SoilInhibitting Insect Pests. in Gaugler Kaya H K. (Ed) Entomophatogenic Nematodes in Biological Control. Florida : CRC Press.

Laznik Z \& Trdan S. 2014. The influence of insecticides on the viability of entomopathogenic nematodes (Rhabditida: Steinernematidae and Heterorhabditidae) under laboratory conditions. Pest Management Science 70:784-789.

Li Y, Mbata GN, Punnuri S, Simmons AM \& Shapiro-Ilan DI. 2021. Bemisia tabaci on vegetables in the Southern United States: incidence, impact, and management. Insects 12:198.

Prabowo H, \& Indrayani IGAA. 2009. Potensi Nematoda Patogen Serangga Steinernema spp. dalam Pengendalian Hama Utama Tanaman Kapas. Buletin Tanaman Tembakau, Serat \& Minyak Industri 1(2), Oktober 2009.

Rezaei N, Karimi J, Hosseini, M, Goldani M, \& Herrera RC. 2015. Pathogenicity of Two Species of Entomopathogenic Nematodes Against the Greenhouse Whitefly, Trialeurodes vaporariorum (Hemiptera: Aleyrodidae), in Laboratory and Greenhouse Experiments. J Nematol 47(1): 60-66.

Setiawati, Udiarto BK, \& Soetiarso TA. 2008. Pengaruh Varietas dan Sistem Tanam Cabai Merah terhadap Penekanan Populasi Hama Kutu Kebul. J. Hortikultura 18(1): 55-61.

Shapiro-Ilan DI, Hazir S \& Glazer I. 2020. Advances in use of entomopathogenic nematodes in IPM. In Kogan, M. and Heinrichs, E. A. (Eds), Integrated Management of Insect Pests: Current and Future Developments Burleigh Dodds Science Publishing, Cambridge, pp. 649-78.

Sugiyama K. 2005. Management of whitefly for commercial tomato production in greenhouses in Shizuoka, Japan Pp. 81-91 in Ku, T.Y. \& Wang C.L (Ed). Proc. of the International Seminar on Whitefly Management and Control Strategy. Taichung, Taiwan, Oct 3-8, 2005. Taichung, Taiwan.

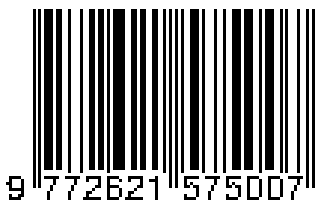

